\title{
TROPHIC MORPHOLOGY OF FIVE BENTHIC-FEEDING FISH SPECIES OF A TROPICAL FLOODPLAIN
}

\author{
FUGI, R., AGOSTINHO, A. A. and HAHN, N. S. \\ Nupélia, Núcleo de Pesquisas em Limnologia, Ictiologia e Aqüicultura, Universidade Estadual de Maringá, \\ Campus Universitário, Av. Colombo, 5790, CEP 87020-900, Maringá, PR, Brazil \\ Correspondence to: Rosemara Fugi, Núcleo de Pesquisas em Limnologia, Ictiologia e Aqüicultura, Universidade \\ Estadual de Maringá, Campus Universitário, Av. Colombo, 5790, CEP 87020-900, Maringá, PR, Brazil \\ Received October 25, 1999 - Accepted May 9, 2000 - Distributed February 28, 2001
}

(With 3 figures)

\begin{abstract}
This study describes the morphology of the digestive apparatus and the size and organic content of the ingested food of five species of benthic-feeding fishes (Prochilodus lineatus, Steindachnerina insculpta, Loricariichthys platymetopon, Trachydoras paraguayensis e Iheringichthys labrosus). The samples were taken in the floodplain of the up Paraná River in February and August 1991. The results suggested that these species have different mouth, teeth, gill rakers, stomach and intestine length. These morphologic characteristics were related with the type, size and nutritional quality of the food ingested. Although these species feed on the bottom, the morphologic divergences probably explain the differences in diet.
\end{abstract}

Key words: trophic morphology, bottom-feeding, Paraná River.

\section{RESUMO}

Morfologia trófica de cinco espécies de peixes comedoras de bentos de uma planície de inundação tropical

A morfologia do aparelho digestivo e alguns aspectos relacionados ao tamanho e ao conteúdo orgânico do alimento ingerido por cinco espécies de peixes com alimentação bentônica (Prochilodus lineatus, Steindachnerina insculpta, Loricariichthys platymetopon, Trachydoras paraguayensis e Iheringichthys labrosus) estão descritos neste estudo. As amostragens foram realizadas na planície de inundação do alto Rio Paraná em fevereiro e agosto de 1991. Os resultados mostraram que a posição da boca, os dentes, os rastros branquiais, o estômago e o comprimento do intestino diferenciam essas espécies, e que essas características estão relacionadas ao tipo, ao tamanho e ao valor nutricional do alimento ingerido. Assim, embora essas espécies se alimentem no fundo, as divergências morfológicas explicam as diferenças na dieta.

Palavras-chave: morfologia trófica, comedores de fundo, Rio Paraná.

\section{INTRODUCTION}

Studies on trophic morphology expanded following the classic work of Suyehiro (1942), AlHussaini (1949), and Angelescu \& Gneri (1949), among others, who demonstrated that a correlation exists between the structures of the digestive apparatus and the feeding habit of fishes. Particular morphological traces give insights on the feeding ecology of a species, since these peculiarities suggest how a fish is able to feed. Wootton (1990) emphasized that there may be evolutionary convergence in the morphology of phylogenetically unrelated species that use similar food resources.

Although the relationship between the morphology of the digestive apparatus and diet of fishes have been well documented (Suyehiro, 1942; AlHussaini, 1949; Angelescu \& Gneri, 1949; Junger 
et al., 1989; Veregina, 1990), the morphological variations within trophic categories in tropical fishes appear to be poorly known, specially among detritivores and other benthic feeding fishes.

Prochilodus lineatus, Steindachnerina ins culpta, Loricariichthys platymetopon, Iheringichthys labrosus, and Trachydoras paraguayensis, are the most abundant bottom-feeders in the Paraná River floodplain (Agostinho et al., 1997). These species are bottom-feeders, and exploit different food resources (Fugi et al., 1996). The present investigation intended to relate the morphology of the trophic apparatus to the ability of these species to consume different benthic food items.

\section{MATERIAL AND METHODS}

The five species studied (P. lineatus, $S$. insculpta, L. platymetopon, I. labrosus, and T. paraguayensis) were collected with gillnets at two sampling stations (a channel and a backwater, both with semi-lentic characteristics), in the floodplain of the up Paraná River (State of Paraná, Brazil), in February and August 1991.

Following capture, the specimens were measured and fixed in $4 \%$ formaldehyde. The shape and position of the mouth, the distribution of the teeth in the different regions of the buccal cavity, and the structures of the gill rakers, stomach, and intestine were determined in 25 specimens of each species. The gill rakers description and the distance between them were taken of each using a steroscopic microscope with an ocular micrometer. These measurements were made only for L. platymetopon and I. labrosus, which have separate rakers. The intestine was separated from the viscera and measured from the insertion of the stomach to the urogenital aperture.

The organic content of the food was estimated by incinerating the stomach contents in a muffle furnace at $550^{\circ} \mathrm{C}$ for three hours. The sizes of the particles and the organisms present in the stomach contents were measured (three samples were taken from each stomach of ten individuals) in order to evaluate possible selective retention in the gills rakers. For those species which ate filiform insect larvae, the lengths of these larvae were measured. The sizes of the particles and organisms were measured with the aid of a steroscopic microscope fitted with an ocular micrometer. For L. platymetopon the food was removed from the anterior third of the intestine.

In order to compare the length of the intestines of the five species, controlling the effect of fish length, a covariance analysis (ANCOVA) was used (Huitema, 1980). The data were log transformed prior to the analysis. The organic matter content of the food (\%) was compared between the species, with a one-way ANOVA (Zar, 1996).

\section{RESULTS}

Comparative morphology of the digestive tract The morphological characteristics of the digestive tract of the species analyzed, as well as the predominant food items in their diets, are shown in Table 1.

Prochilodus lineatus has terminal mouth and well-developed and very protractible lips. In $S$. insculpta and I. labrosus the mouth is sub-terminal and in the first species has spatular jaw. Trachydoras paraguayensis have inferior mouth. In $L$. platymetopon the mouth is ventral and suking. Steindachnerina insculpta does not have teeth. On the other hand, the teeth are small, mobile and restrict to the lips in P. lineatus. L. platymetopon has teeth in the premaxillary and dentary and pharyngeal teeth. T. paraguayensis has only pharyngeal teeth. P. lineatus, $S$. insculpta and T. paraguayensis have short gills rakers which are numerous and linked. In L. platymetopon the rakers of the first arch are short and with spaces gaps between them. I. labrosus has in the first branquial arch longer and spaced rakers compared with the other species. The stomachs of P. lineatus and S. insculpta have two regions very delimited, cardic and piloric (gizzard). The stomachs of I. labrosus and T. paraguayensis are sacciform with the cardid and piloric regions not well differentiated.

\section{Relationship of intestine length to standard length}

The slopes of the relationships between gut and fish length were not different for the five species $(F=0.751 ; P=0.558)$. The common angular coefficient of 0.961 , was significantly different from zero $(F=278.72 ; P<0.001)$, indicating a strong linear relationship between log LI and log SL. The gut length differed between the five species $(F=2,590.1 ; P<0.001)$. 
TABLE 1

Main morphological characteristics of mouth, teeth, gill rakers, stomach, intestine and main food of five fish species $(\mathrm{CI}=$ Confidence Interval).

\begin{tabular}{|c|c|c|c|c|c|c|}
\hline Species & Mouth & Teeth & Gill rakers & Stomach & Intestine & * Main food \\
\hline P. lineatus & $\begin{array}{l}\text { Terminal } \\
\text { and } \\
\text { protractible } \\
\text { lips }\end{array}$ & $\begin{array}{c}\text { Smaller and } \\
\text { movables } \\
\text { labial teeth }\end{array}$ & $\begin{array}{c}\text { Numerous, shorts } \\
\text { and juxtaposed }\end{array}$ & $\begin{array}{l}\text { Chemic (cardic) } \\
\text { and mechanic } \\
\text { (gizzard), } \\
\text { elongated and } \\
\text { with similar } \\
\text { dimension; } \\
\text { numerous piloric } \\
\text { ceca }\end{array}$ & $\begin{array}{l}\text { Longest, } \\
\text { with folds } \\
\text { of the } \\
\text { mucosa }\end{array}$ & $\begin{array}{c}\text { Finely divided } \\
\text { sediment and } \\
\text { detritus }\end{array}$ \\
\hline S. insculpta & $\begin{array}{l}\text { Subterminal } \\
\text { spatular jaw, } \\
\text { lightly } \\
\text { protract }\end{array}$ & Absent & $\begin{array}{c}\text { Numerous, shorts } \\
\text { and juxtaposed }\end{array}$ & $\begin{array}{l}\text { Chemic (cardic) } \\
\text { and mechanic } \\
\text { (gizzard), } \\
\text { sacciform, the } \\
\text { latter is bigger; a } \\
\text { little piloric ceca }\end{array}$ & $\begin{array}{l}\text { Very long } \\
\text { and slender }\end{array}$ & $\begin{array}{c}\text { Finely divided } \\
\text { sediment and } \\
\text { detritus }\end{array}$ \\
\hline L. platymetopon & $\begin{array}{l}\text { Ventral and } \\
\text { sucking }\end{array}$ & $\begin{array}{l}\text { Premaxillary } \\
\text { and dentary } \\
\text { teeth; } \\
\text { pharyngeal } \\
\text { teeth very } \\
\text { developed }\end{array}$ & $\begin{array}{c}\text { Short. Gap } \\
\text { between rakers: } \\
125-187.5 \mu \mathrm{m} ; \\
\mathrm{X}=152.7 \pm 4.6 \mathrm{CI}\end{array}$ & Absent & Short & $\begin{array}{l}\text { Large detritus } \\
\text { particles, } \\
\text { benthic } \\
\text { organisms }\end{array}$ \\
\hline T. paraguayensis & Inferior & $\begin{array}{c}\text { Pharyngeal } \\
\text { teeth }\end{array}$ & $\begin{array}{l}\text { Numerous and } \\
\text { shorts }\end{array}$ & Sacciform & Short & $\begin{array}{c}\text { Microcrusta- } \\
\text { ceans and } \\
\text { Testacea }\end{array}$ \\
\hline I. labrosus & Subinferior & $\begin{array}{c}\text { Dentigerous } \\
\text { plates in the } \\
\text { premaxillary, } \\
\text { dentary and } \\
\text { pharyngeal }\end{array}$ & $\begin{array}{c}\text { Long. Gap between } \\
\text { rakers: } \\
218.8-364.5 \mu \mathrm{m} ; \\
\bar{X}=256.0 \pm 10.0 \mathrm{CI}\end{array}$ & Sacciform & Short & Chironomidae \\
\hline
\end{tabular}

* From Fugi et al. (1996).

The adjusted means for intestinal length decreased in the following order: S. insculpta $>P$. lineatus $>$ L. platymetopon $>T$. paraguayensis $>$ I. labrosus (Fig. 1).

\section{Organic matter content and size of particles and organisms}

The relative amount of organic matter in the stomach contents differed significantly among species $(F=124.119 ; P<0.001)$. The means increased in the order: $P$. lineatus $<S$. insculpta $<$ L. platymetopon $<$ I. labrosus $<T$. paraguayensis (Fig. 2). According Scheffé test applied for post hoc comparisons, only organic matter means for L. platymetopon and $S$. insculpta were not statistically different $(P=0.103165)$.

The particles present in the gastric contents were smaller than $550 \mu \mathrm{m}$ for all species, except
I. labrosus, which ingested items up to $1,435 \mu \mathrm{m}$. The particles ingested by $P$. lineatus and $S$. insculpta had sizes predominantly (>80\%) between 35 and $105 \mu \mathrm{m}$. For L. platymetopon the highest frequencies were observed for the 35 to $175 \mu \mathrm{m}$ size classes, and for T. paraguyensis between 105 and $245 \mu \mathrm{m}$. Iheringichthys labrosus, which varied most in size, had a greater frequency of the smallest size items considered (35 $\mu \mathrm{m})$ (Fig. 3 ).

\section{DISCUSSION}

In all five species, the position of the mouth was suitable for obtaining food from the bottom. Although P. lineatus has a terminal mouth, inappropriate for bottom-feeding, its well-developed and very protractible lips allow it to obtain food without changing its general body position. 


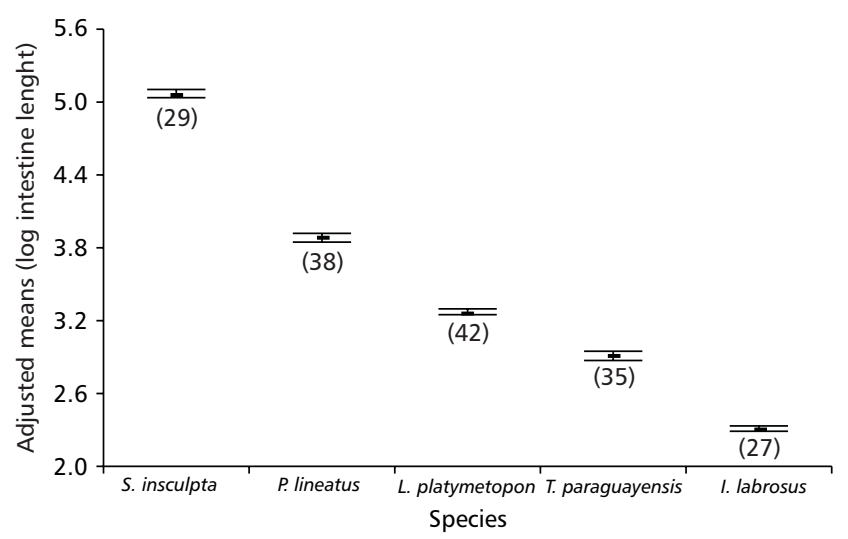

Fig. 1 - Adjusted means and standard error of intestine length (number in parentheses = sample size) of five fish species.

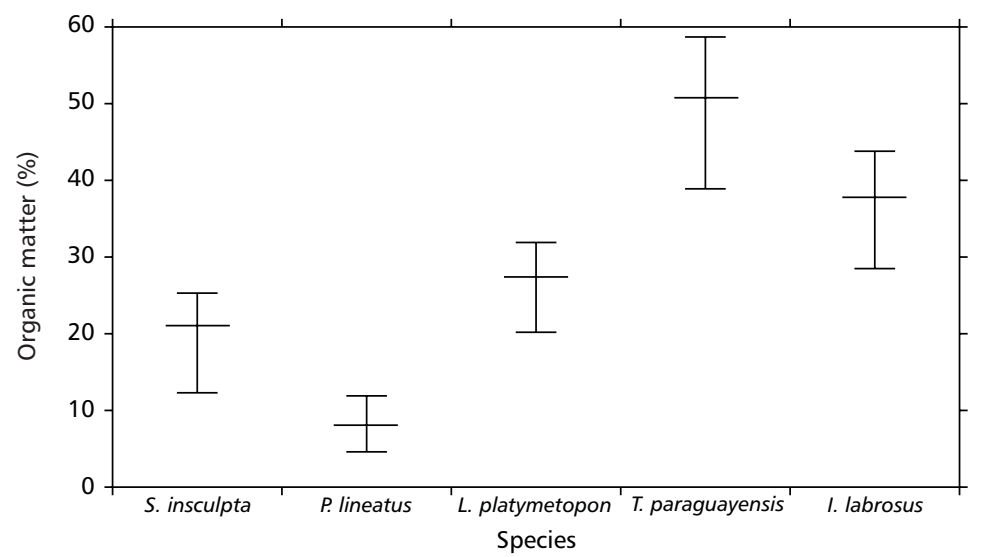

Fig. 2 - Mean values of the relative amount organic matter of the stomach contents (mean, minimum and maximum values) of five fish species.

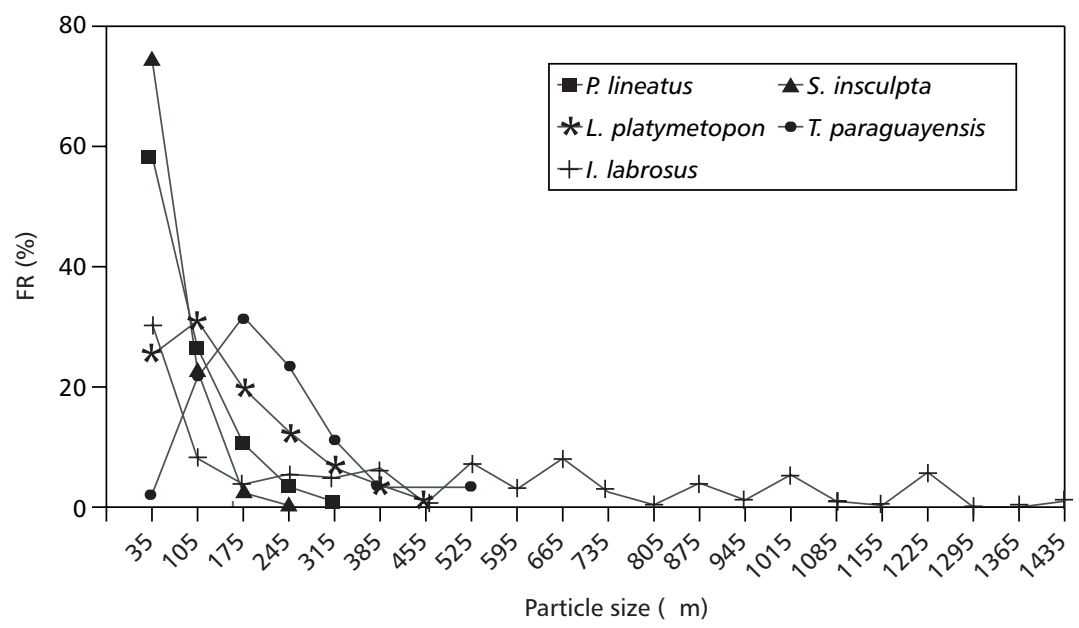

Fig. 3 - Frequency distribution by size class of the food particles of the stomach contents of five fish species. 
Goulding (1981) mentioned that Prochilodus nigricans uses its lips to remove detritus from the bottom and other substrates. In S. insculpta, the subterminal mouth and shovel-shaped dentary allow it to dig in the substrate. This behavior has been described for other curimatids (Sazima \& Caramaschi, 1989). Loricariichthys platymetopon, with ventral mouth, was the most adapted to the bottomfeeding habit. In this species, the cup-shaped mouth aids in suction of detritus. Trachydoras paraguayensis and I. labrosus have small mouths in inferior and sub-inferior positions respectively, which allows them to select their food, based on benthic invertebrates (Fugi et al., 1996).

The relationship of the position and form of the teeth has been discussed by Al-Hussaini (1949), Angelescu \& Gneri (1949) and Blaber et al. (1994), and is considered an important adaptation resulting from evolutionary processes mediated by the nature of the food (Veregina, 1990). Prochilodus lineatus and $S$. insculpta have rudimentary or no teeth. The food consumed by both species, basically mud and fine particulate detritus, does not require the presence of well-developed teeth, since they do not need these structures to ingest or hold the food. Veregina (1990) stated in this context that a common adaptation for the detritivore feeding regime is the partial or complete reduction of the teeth. The small labial teeth present in P. lineatus, on the other hand, must aid in scraping the periphyton from the substrate.

The rudimentary teeth implanted in the premaxillary and dentary of L. platymetopon must also function to scrape the surfaces of substrates, before the food is sucked in. The dentigerous plates in I. labrosus suggest a function for grasping small organisms harvested in the sediment. In both cases, these statements find support in the type of food ingested (large detritus particles in the case of L. platymetopon, and benthic organisms in I. labrosus).

Pharyngeal teeth, found in L. platymetopon, I. labrosus, and T. paraguayensis, are responsible for grinding or dismembering food (Lagler et al., 1977). The presence of these teeth is associated with the absence of a well-defined stomach, especially the mechanical function, since the teeth assume part of the function of the stomach (Angelescu \& Gneri, 1949).
The selective retention of food by the gill rakers has been mentioned by Angelescu \& Gneri (1949), Keenleyside (1975), and Hoogenboezem et al. (1991). In the present study, adaptations of the gill rakers to the feeding regime were observed in all the species, most obviously when the size of the food ingested was compared to the space between the gill rakers. Prochilodus lineatus, $S$. insculpta, and T. paraguayensis, which consume mainly small particles of detritus, mud and small organisms (microcrustaceans and Testacea), have the rakers quite close together, preventing loss of food through the gill net. On the other hand, the branchial structure of L. platymetopon and I. labrosus has a selective function. These species, particularly I. labrosus, which consumes larger food items, has well-spaced rakers, permitting rejection of undesirable particles such as sand grains. The latter, which has the greatest distance between the rakers, consumed relatively large organisms (Chironomidae). Lammens \& Hoogenboezem (1991) observed that for benthophagous fishes, large sand particles do not pass through the rakers and are spat out, while the small grains are eliminated through the channels formed by the rakers.

The conformation of the stomachs of the species studied suggests that $P$. lineatus and $S$. insculpta are strongly adapted to the iliophagous feeding regime. Their diet, based on items that are difficult to digest (mud and detritus), necessitate mechanical action, which in these species are performed by the well-developed gizzard-shaped pyloric stomach. This type of stomach mainly fragments the food (Odum, 1968). According to Veregina (1990), the grinding is assisted by small mineral particles that accompany the food. On the other hand, L. platymetopon has an accessory structure that has been described as a stomach (Angelescu \& Gneri, 1949; Py-Daniel, 1984), although Silva et al. (1997) concluded that this structure is an accessory organ adapted for aerial respiration. This is an adaptation to low dissolved oxygen concentrations that occur occasionally in the Upper Paraná River floodplain (Thomaz et al., 1997). Iheringichthys labrosus and T. paraguayensis have sacciform stomachs, common among fishes.

The intestine has been thoroughly studied as the structure of the digestive apparatus related to diet, with certain patterns precisely defined. Accor- 
ding to Fryer \& Iles (1972), the length of the intestine is clearly related to the trophic status of the species, and its length is ordered in the following way: carnivores < omnivores $<$ herbivores $<$ detritivores. Prochilodus lineatus and $S$. insculpta, which feed exclusively on finely particulate detritus and mud (Fugi et al., 1996), have the longest intestines. In these species the length of the intestine is an adaptation for consuming food that is difficult to digest and assimilate, and which requires a large area for absorption. This becomes evident when we consider the proportion of organic matter in their stomach contents, which were low in both species. The fact that $P$. lineatus has a shorter intestine than $S$. insculpta, having ingested food with lower organic content, can be explained by the presence of folds in the intestine which increase the area of absorption. On the other hand, T. paraguayensis and I. labrosus have shorter intestines, which are related to a diet based on benthic organisms with high nutritional value, as shown by the higher values of organic matter found in their stomach contents. Junger et al. (1989) stated that short intestines indicate a tendency to carnivory. Intermediate intestinal lengths were recorded for L. platymetopon, which feeds on large detritus particles and a certain amount of benthic organisms. The data for organic matter also corroborate these results, since these values were higher than in P. lineatus and S. insculpta, and lower than in T. paraguayensis and I. labrosus. Bowen (1983) suggested that this relationship be interpreted as a result of the resistance of different foods to digestion by intestine enzymes.

Although the five species are all bottomfeeders, different aspects of their morphology directly reflect the food resources that they exploit.

Acknowledgments - We acknowledge the comments of Sidinei M. Thomaz and the statistical support and suggestion of Luis M. Bini.

\section{REFERENCES}

AGOSTINHO, A. A., HAHN, N. S., GOMES, L. C. \& BINI, L. M., 1997, Estrutura trófica, pp. 229-248. In: A. E. A. M. Vazzoler, A. A. Agostinho \& N. S. Hahn (eds.), A planície de inundação do alto Rio Paraná: aspectos físicos, biológicos e socioeconômicos. 460p., EDUEM, Nupélia, Maringá.

AL-HUSSAINI, A. H., 1949, On the functional morphology of the alimentary tract of some fish in relation to differen ces in their feeding habits: anatomy and histology. Quart. Journ. Micr. Sci., 90(2): 109-139.
ANGELESCU, V. \& GNERI, F. S., 1949, Adaptaciones del aparato digestivo al régimen alimenticio en algunos peces del Río Uruguay y Río de La Plata. Rev. Inst. Nac. Invest. Nat., 1: 161-281.

BLABER, S. J. M., BREWER, D. T. \& SALINI, J. P., 1994, Diet and dentition in tropical ariid catfishes from Australia. Environ. Biol. fishes, 40: 159-174.

BOWEN, S. H., 1983, Detritivory in neotropical fish communities. Environ. Biol. Fishes, 9(2): 137-144.

FRYER, G. \& ILES, T. D., 1972, The cichlid fishes of the Great Lakes of Africa. Edinburg: Oliver and Boyd.

FUGI, R., HAHN, N. S. \& AGOSTINHO, A. A., 1996, Feeding styles of five species of bottom-feeding fishes of the High Paraná River. Environ. Biol. Fishes, 46: 297307.

GOULDING, M., 1981, The fishes and the forest: exploration in Amazoniam Natural History. University of California Press, Berkeley, 280p.

HOOGENBOEZEM, W., BOOGAART, J. G. M., SIBBING, F. A., LAMMENS, E. H. R., TERLOUW, A. \& OSSE, J. W. M., 1991, A new model of particle retention and branchial sieve adjustment in filter-feeding bream (Abramis brama, Cyprinidae). Can. J. Fish. Aquat. Sci., 48(1): 718.

HUITEMA, B. E., 1980, The analysis of covariance and alternatives. John Wiley \& Sons, New York, 445p.

JUNGER, H., KOTRSCHOR, K. \& GOLDCHMID, A., 1989, Comparative morphology and ecomorphology of the gut in European cyprinids. J. Fish Biol., 34: 315-326.

KEENLEYSIDE, M. H. A., 1975, Feeding behavior, pp. 1743. In: W. S. Hoar, B. Hoelldobler, K. Johansen, H. Langer \& M. Lindauer (eds.), Diversity and adaptation in fish behaviour. Springer-Verlag, Berlim.

LAGLER, K. F., BARDACH, J. E., MILLER, R. R. \& PASSINO, D. R., 1977, Ichthyology. John Wiley \& Sons, New Jersey, 506p.

LAMMENS, E. H. R. \& HOOGENBOEZEM, W., 1991, Diets and feeding behaviour, pp. 353-376. In: I. J. Wintified \& J. Nelson (eds.), Cyprinid fishes systematics, biology and exploitation. London, Chapman and Hall.

ODUM, H. E., 1968, The ecological significance of fine particle selection by striped mullet Mugil cephalus. Limnol. Oceanogr., 13: 92-97.

PY-DANIEL, L. H. R., 1984, Sistemática dos Loricariidae (Ostariophysi, Siluroidei) do complexo de lagos do Janauacá, Amazonas, e aspectos de sua bilogia e ecologia. Master Thesis, Instituto Nacional da Amazônia, Fundação Universidade do Amazonas, 278p.

SAZIMA, I. \& CARAMASCHI, E. P., 1989, Comportamento alimentar de duas espécies de Curimata, sintópicas no Pantanal de Mato Grosso (Osteichthyes, Characiformes). Rev. Brasil. Biol., 49(2): 325-333.

SILVA, J. M., HERNANDEZ-BLAZQUEZ, F. J. \& JULIO-JR., H. F., 1997, A new accessory respiratory organ in fishs: morphology of the respiratory purses of Loricariithys platymetopon (Pisces, Loricariidae). Annales des Sciences Naturelles, Zoologie, Paris, 18(3): 93-103. 
SUYEHIRO, Y., 1942, A study on the digestive system and feeding habits of fish. Jap. J. Zool., 10: 1-303.

THOMAZ, S. M., ROBERTO, M. C. \& BINI, L. M., 1997, Caracterização limnológica dos ambientes aquáticos e influência dos níveis fluviométricos, pp. 73-102. In: A. E. A. M. Vazzoler, A. A. Agostinho \& N. S. Hahn (eds.), A planície de inundação do alto Rio Paraná: aspectos físicos, biológicos e socioeconômicos, 460p. EDUEM, Nupélia, Maringá.
VEREGINA, I. A., 1990, Basic adaptations of the digestive system in bony fishes as a function of diet. J. Ichthyology, 30(6): 897-907.

WOOTTON, R. J., 1990, Ecology of teleost fishes. Chapman \& Hall, London, 404p.

ZAR, J. H., 1996, Biostatistical analyses. Printice Hall, New Jersey, 662p. 